\title{
NFIB-Mediated Repression of the Epigenetic Factor Ezh2 Regulates Cortical Development
}

\author{
Michael Piper, ${ }^{1,3 *}$ Guy Barry, ${ }^{1 *}$ Tracey J. Harvey, ${ }^{1}$ Robert McLeay, ${ }^{2}$ Aaron G. Smith, ${ }^{2}$ Lachlan Harris, ${ }^{3}$ Sharon Mason, ${ }^{1}$ \\ Brett W. Stringer, ${ }^{4}$ Bryan W. Day, ${ }^{4}$ Naomi R. Wray, ${ }^{1}$ Richard M. Gronostajski, ${ }^{5}$ Timothy L. Bailey, ${ }^{2}$ Andrew W. Boyd, ${ }^{4}$ \\ and Linda J. Richards ${ }^{1,3}$ \\ ${ }^{1}$ Queensland Brain Institute, ${ }^{2}$ Institute for Molecular Bioscience, and ${ }^{3}$ The School of Biomedical Sciences, The University of Queensland, Brisbane, Australia \\ 4069, ${ }^{4}$ QIMR Berghofer Medical Research Institute, Brisbane, Australia 4029, and ${ }^{5}$ Department of Biochemistry, Program in Genetics, Genomics and \\ Bioinformatics, Center of Excellence in Bioinformatics and Life Sciences, State University of New York at Buffalo, Buffalo, New York 14203
}

Epigenetic mechanisms are essential in regulating neural progenitor cell self-renewal, with the chromatin-modifying protein Enhancer of zeste homolog 2 (EZH2) emerging as a central player in promoting progenitor cell self-renewal during cortical development. Despite this, how Ezh2 is itself regulated remains unclear. Here, we demonstrate that the transcription factor nuclear factor IB (NFIB) plays a key role in this process. $\mathrm{Nfib}{ }^{-1-}$ mice exhibit an increased number of proliferative ventricular zone cells that express progenitor cell markers and upregulation of EZH2 expression within the neocortex and hippocampus. NFIB binds to the Ezh2 promoter and overexpression of NFIB represses Ezh2 transcription. Finally, key downstream targets of EZH2-mediated epigenetic repression are misregulated in $\mathrm{Nfib}{ }^{-/-}$ mice. Collectively, these results suggest that the downregulation of Ezh2 transcription by NFIB is an important component of the process of neural progenitor cell differentiation during cortical development.

Key words: cortex; Ezh2; hippocampus; neural progenitor cell; Nfib

\section{Introduction}

Development of the brain requires a tightly controlled program of progenitor cell proliferation and differentiation. Recent advances have provided insights into how this is controlled. For example, Notch signaling regulates both progenitor self-renewal and gliogenesis (Kageyama et al., 2008). Interestingly, recent evidence has implicated epigenetic control of transcription as being central to the self-renewal of progenitor cells (Meaney and Ferguson-Smith, 2010). For instance, the epigenetic mark induced by the polycomb repressive complex 2 factor Enhancer of zeste homolog 2 (EZH2) results in the widespread repression of regulatory genes re-

\footnotetext{
Received May 30, 2013; revised Jan. 9, 2014; accepted Jan. 14, 2014.

Author contributions: M.P., G.B., and L.J.R. designed research; M.P., G.B., T.H., A.S., L.H., S.M., B.S., and B.D. performed research; R.G., T.B., and A.B. contributed unpublished reagents/analytic tools; M.P., G.B., T.H., R.M., A.S., B.S., B.D., N.W., R.G., T.B., A.B., and L.J.R. analyzed data; M.P., G.B., and L.J.R. wrote the paper.

This work was supported by the National Health and Medical Research Council (NHMRC; Project Grant APP1022308 to M.P., L.J.R., T.L.B., and A.W.B.), the Australian Research Council (Grant DP0984643 to L.J.R.), Cancer Council Queensland (grant to L.J.R., A.W.B., and M.P.), New York State Stem Cell Science (Grant C026429 to R.M.G.), and the National Institutes of Health (Grant HL080624 to R.M.G.). The content is solely the responsibility of the authors and does not necessarily represent the official views of the NHMRC or the Australian Research Council. L.J.R. was supported by an NHMRC Principal Research Fellowship. M.P. and N.R.W. were supported by Australian Research Council Future Fellowships FT120100170 and FT0991360. We thank John Baisden, Kathleen Cato, Chantelle Dixon, and Erica Little for technical assistance and Rowan Tweedale for critical reading of the manuscript.

${ }^{*} M . P$. and G.B. contributed equally to this work.

Correspondence should be addressed to either Linda J. Richards or Michael Piper, The School of Biomedical Sciences and the Queensland Brain Institute, The University of Queensland, Brisbane, Queensland 4072, Australia. E-mail:m.piper@uq.edu.au or richards@uq.edu.au.

DOI:10.1523/JNEUROSCI.2319-13.2014

Copyright $\odot 2014$ the authors $\quad 0270-6474 / 14 / 342921-10 \$ 15.00 / 0$
}

sponsible for lineage determination (Boyer et al., 2006, Lee et al., 2006); therefore, EZH2 promotes progenitor cell selfrenewal. This finding has recently been extended to reveal a role for EZH2 in maintaining cortical neural progenitor cell identity (Sher et al., 2012). Moreover, ablation of Ezh2 at midembryogenesis in the cerebral cortex results in precocious neural progenitor cell differentiation (Pereira et al., 2010), demonstrating that EZH2 regulates embryonic neural progenitor cell self-renewal. However, the transcriptional regulation of Ezh2 during corticogenesis remains unclear.

The nuclear factor I (NFI) family of transcription factors has been implicated in driving neural progenitor cell differentiation. For example, NFIB is expressed by neural progenitor cells and mice lacking this transcription factor exhibit deficits in the production of postmitotic progeny within the developing telencephalon (Barry et al., 2008, Piper et al., 2009) and spinal cord (Deneen et al., 2006). However, the underlying process behind NFIB-mediated neural progenitor cell differentiation remains unclear. To investigate this, we performed a microarray screen within the hippocampus of $\mathrm{Nfib}^{-/-}$mice to identify potential NFIB targets. This experiment identified numerous chromatin-modifying genes as being upregulated in the mutant, including Ezh2. Using analysis of $\mathrm{Nfib}^{-1-}$ mice and a suite of molecular and bioinformatics techniques, we reveal here that Ezh2 is a target for transcriptional repression by NFIB, suggesting that the deficits in neural progenitor cell differentiation evident within $\mathrm{Nfib}^{-1-}$ mice (Barry et al., 2008) may be due, at least in part, to the loss of NFIB-mediated repression of this epigenetic regulator. 


\section{Materials and Methods}

Animals. $\mathrm{Nfib}^{-1-}$ and $\mathrm{Nfib}^{+/+}$littermate mice of either sex (SteelePerkins et al., 2005) were used in this study with approval from the University of Queensland animal ethics committee and experiments were performed according to the Australian Code of Practice for the Care and Use of Animals for Scientific Purposes.

Immunohistochemistry. Embryos were drop-fixed in 4\% paraformaldehyde (PFA) at embryonic day 14 (E14) or below or transcardially perfused with $0.9 \%$ saline, followed by $4 \%$ PFA (E16, E18), and were then postfixed in $4 \%$ PFA at $4^{\circ} \mathrm{C}$. Brains were paraffin embedded and sectioned coronally at $6 \mu \mathrm{m}$. Immunohistochemistry using the chromogen 3,3'-diaminobenzidine was performed as described previously (Piper et al., 2010) using the following rabbit polyclonal antibodies: anti-PAX6 (AB2237, 1/1000; Millipore), anti-SOX2 (catalog \#2748, 1/1000; Cell Signaling Technology), anti-EZH2 (catalog \#39639, 1/1000; Active Motif), and anti-phosphohistone H3 (catalog \#06-570, 1/1000; Millipore). Biotin-conjugated goat anti-rabbit IgG (BA-1000; Vector Laboratories) secondary antibodies were used for chromogenic immunohistochemistry at $1 / 1000$. Immunohistochemistry on paraffin sections using fluorescent secondary antibodies was performed as described previously (Piper et al., 2010) using the following antibodies: anti-PAX6 (1/100), anti EZH2 (mouse monoclonal clone AC22, 1/50; Cell Signaling Technology), anti-NFIB (rabbit polyclonal, HPA003956, 1/100; Sigma). Goat-anti rabbit IgG Alexa Fluor 594 and goatanti-rabbit IgG Alexa Fluor 488 (Invitrogen) were used for fluorescence immunohistochemistry at $1 / 100$. Nuclei were counterstained with DAPI.

Quantification of ventricular zone width/hippocampal cell counts. To measure the ventricular zone width in E14-E18 wild-type and $N \mathrm{fib}^{-1-}$ brains, $6 \mu \mathrm{m}$ paraffin sections were hematoxylin stained and imaged with an upright microscope coupled to AxioVision software (Zeiss). The width of the ventricular zone was measured at three points along the hippocampus for each section. Data for both wildtype and knock-out hippocampi at each age were then pooled for comparison of ventricular zone width. This analysis was further performed at two different histological levels along the rostrocaudal axis of the brain at each age. For phosphohistone H3-, PAX6-, SOX2and EZH2-expressing cell counts, the total number of immunopositive cells per $100 \mu \mathrm{m}$ in the ventricular zone of the neocortex and hippocampus of the wild-type and mutant was counted. This analysis was conducted at three points within the hippocampus or neocortex in each case, with data for each section then being pooled for comparison of cell numbers. For the analysis of EZH2/PAX6-expressing cells via immunofluorescence, $6 \mu \mathrm{m}$ paraffin sections were processed for immunofluorescence staining and imaged with an upright fluorescence microscope coupled to AxioVision software (Zeiss). The number of ventricular zone cells per $100 \mu \mathrm{m}$ with the neocortex and hippocampus expressing both EZH2 and PAX6 was then quantified. This analysis was conducted at three points within the hippocampus or neocortex in each case, with data for each section then being pooled for comparison of cell numbers. For all analyses, six $\mathrm{Nfib}^{+/+}$and six $\mathrm{Nfib}^{-1-}$ brains were analyzed. Quantification was performed blind to the genotype of the sample. Statistical analyses were per-
Table 1. qPCR primer sequences used in this study

\begin{tabular}{|c|c|c|}
\hline Gene & Forward primer & Reverse primer \\
\hline Ink4A, exon 16 & AGGTGCCTCAACGCCGAAG & CTGGTCCAGGATTCCGGTGCGG \\
\hline Ink4A, exon 2 & ATGGGCAACGTTCACGTAGCAGC & AGCGGTACACAAAGACCACCCA \\
\hline $\operatorname{lnk} 4 B$ & TAGCGCTCGAGCGTTCCCA & TGTGGCAGAAATGGTCCTTC \\
\hline $\operatorname{lnk} 4 \mathrm{C}$ & AGCCTTGGGGGAACGAGTT & TGCAGCGCAGTCCTTCCAA \\
\hline $\operatorname{lnk} 4 D$ & GAGTTCTGATCCAGCTCTTG & TCTTCCAGAAGCATAGTGGAT \\
\hline Ezh2 & TAGGGAGTGTTCAGTCACCA & AACAGTTTCGTCTTCCACCAT \\
\hline Pax6 & ACGTATATCCCAGTTCTCAGA & ATTCACTCCGCTGTGACTGT \\
\hline Nestin & GAAGTGGCTACATACAGGAC & AGCTTCAGCTTGGGGTCAG \\
\hline Hprt & GCAGTACAGCCCCAAAATGG & AACAAAGTCTGGCCTGTATCCAA \\
\hline Olig1 & ACAGGCAGCCACCTATCTCC & GTTCAGCGAGCGGAGCTT \\
\hline Id4 & GAAGAGCAATCGTGAATCCAAC & GTTCCCCGCCCTGTTATAATC \\
\hline DII1 & TTCTCTGGCTTCAACTGTGAG & СATTGTCCTCGCAGTACCTC \\
\hline Prox 1 & GTCCGACATCTCACCTTATTCAG & TCTGTTGAACTTCACGTCCG \\
\hline Sox3 & GCGACATGATCAGCATGTACC & GCCCTGGTAGTGCTGGTG \\
\hline Sox2 & CCAATCCCATCCAAATTAACGC & СTATACATGGTCCGATTCCCC \\
\hline Hes5 & CCAAGGAGAAAAACCGACTG & AACTCCTGCTCCAGCAGCA \\
\hline Gfap & AGTGGTATCGGTCTAAGTTTG & CGATAGTCGTTAGCTTCGTG \\
\hline
\end{tabular}
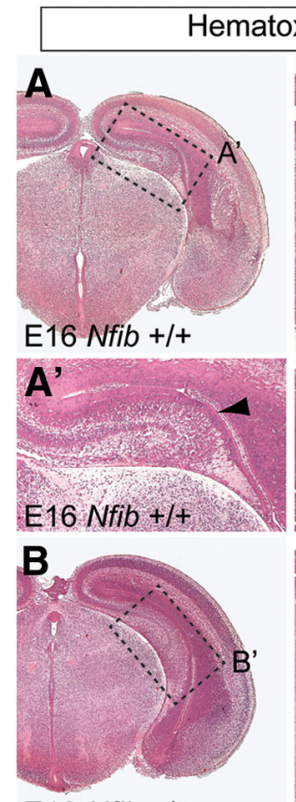

E16 Nfib +/+
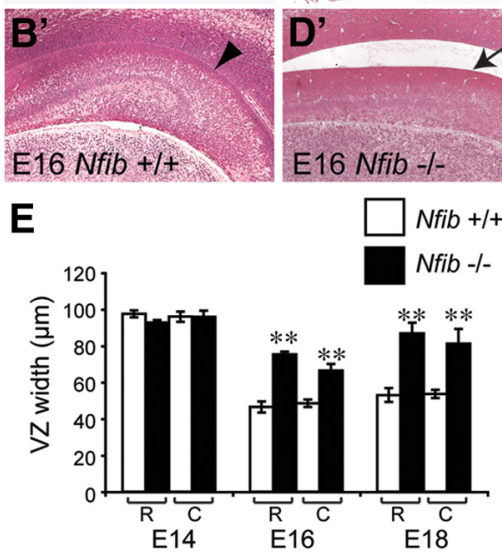
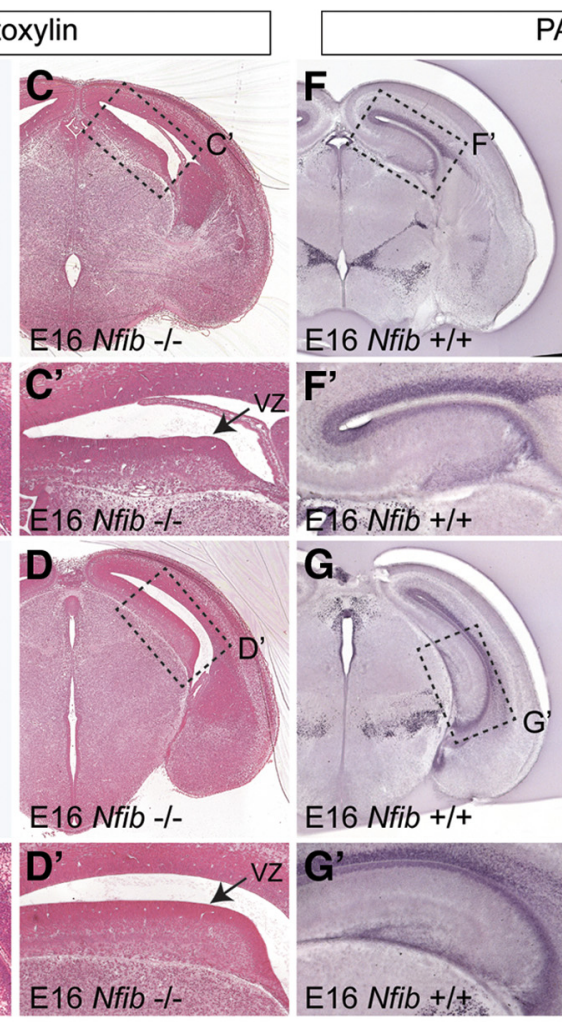

PAX6

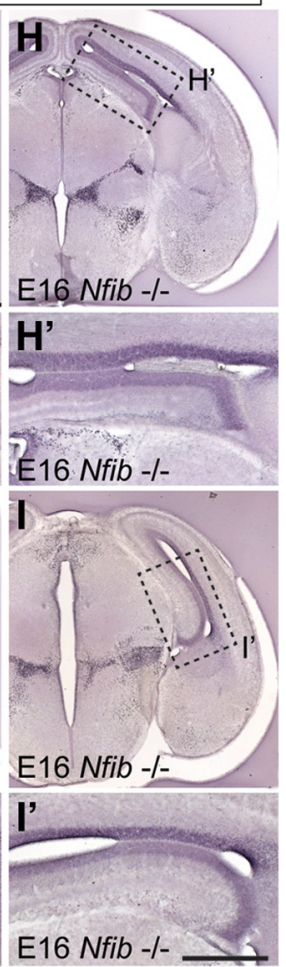

$\mathbf{J}$

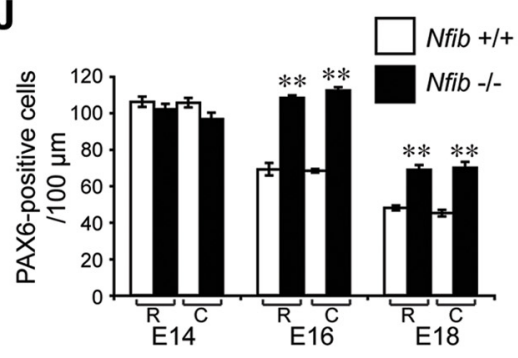

Figure 1. Expansion of the ventricular zone in $\mathrm{Nfib}^{-/-}$mice. A-D, Coronal sections of E16 $\mathrm{Nfib}^{+/+}$and $\mathrm{Nfib}^{-/-}$brains stained with hematoxylin. The ventricular zone (VZ) was significantly wider in the mutant (arrow in $\boldsymbol{C}^{\prime}, \mathbf{D}^{\prime}$ ) compared with controls (arrowheads in $\left.\boldsymbol{A}^{\prime}, \boldsymbol{B}^{\prime}\right)$ at E16 and E18, but not at E14 $(\boldsymbol{E})$. Sections were analyzed at rostral $(\boldsymbol{A}, \boldsymbol{C}$ ) and caudal $(\boldsymbol{B}, \boldsymbol{D})$ levels of the hippocampus. $\boldsymbol{F}-\boldsymbol{I}$, PAX6 immunohistochemistry on coronal paraffin sections of E16 brains. The level of PAX6 expression in neural progenitor cells was comparable between wild-type and mutant brains. However, there were significantly more cells expressing PAX6 in the mutant hippocampus at rostral $(\boldsymbol{H})$ and caudal $(\boldsymbol{I})$ levels compared with controls $(\boldsymbol{F}, \boldsymbol{G})$ at E16 and E18, but not E14 $(\boldsymbol{J})$. $r$, Rostral; c, caudal. ${ }^{* *} p<0.01, t$ test. Scale bars: $\boldsymbol{A}-\boldsymbol{D}, \boldsymbol{F}-\boldsymbol{I}, 600 \mu \mathrm{m} ; \boldsymbol{A}^{\prime}-\boldsymbol{D}^{\prime}, \boldsymbol{F}^{\prime}-\boldsymbol{I}^{\prime}, 250 \mu \mathrm{m}$. 
formed using a two-tailed unpaired $t$ test. Error bars represent the SEM.

Birth-dating experiments. To analyze cell cycle exit, pregnant dams were injected with $100 \mathrm{mg} / \mathrm{kg}$ 5-bromo-2'-deoxyuridine (BrdU) at E15 and then with $100 \mathrm{mg} / \mathrm{kg}$ 5-ethynyl-2'-deoxyuridine (EdU) $1 \mathrm{~d}$ later at E16. Two hours after the EdU treatment, embryos were collected and perfused before being processed for immunofluorescence staining using an anti-BrdU antibody (G3G4, 1/10; Developmental Hybridoma Studies Bank) and a EdU detection kit (Click-iT EdU cell proliferation kit; Life Technologies). Sections were imaged with a confocal microscope (LSM 510 META; Zeiss) using Zen software (Zeiss). The number of cells positive for both BrdU and EdU was calculated as a proportion of the total number of cells positive for BrdU. For this analysis, five $\mathrm{Nfib}^{+/+}$and five $\mathrm{Nfib}^{-/-}$brains were analyzed. Quantification was performed blind to the genotype of the sample. Statistical analyses were performed using a two-tailed unpaired $t$ test. Error bars represent the SEM.

Hippocampal microarrays. Hippocampi from E16 wild-type $(n=4)$ and $\mathrm{Nfib}^{-1-}(n=3)$ mice were dissected, RNA was extracted, and gene expression profiles were obtained as described previously (Piper et al., 2010). Differential expression was determined by the one-way ANOVA-Welch's approximate $t$ test without a multiple testing correction. A cutoff $p$-value of 0.05 was used for the mean difference between wild-type and $\mathrm{Nfib}^{-1-}$ tissue. In addition, a 1.5-fold change filter was imposed. Pathway analysis was performed using the DAVID Bioinformatics Resources 6.7 (http://david.abcc.ncifcrf.gov/; Huang da et al., 2009).

In silico promoter analysis. In silico promoter analysis was performed using the binding motif TTGGC(N5)GCCAA. Full details of the scanning method used and how we controlled for false discovery rate have been described previously (Piper et al., 2010).

Quantitative real-time PCR. Cortical and hippocampal samples were collected and snap frozen. RNA was extracted (RNeasy Micro Kit; Qiagen) and reverse transcription was performed. RNA was isolated from cell lines in the same manner. Quantitative real-time PCR (qPCR) data expression and analysis were performed as described previously (Piper et al., 2010). For all qPCR analyses, RNA from at least three independent replicates for $\mathrm{Nfib}^{+/+}$and $\mathrm{Nfib}^{-1-}$ mice or control and treated cells were interrogated. All the samples were tested in triplicate and each experiment was repeated a minimum of three times. The housekeeping gene hypoxanthine phosphoribosyltransferase 1 was used to calculate relative changes in gene expression level, which is presented as $-\Delta \mathrm{Ct}$ (Yuan et al., 2006). Statistical analyses were performed using a one-sided Wilcoxon rank-sum test. Because each test was based on a directional hypothesis, the one-sided test was justified. When the sample size is 3 , the minimum $p$-value achievable from this nonparametric test is 0.05 . Therefore, tests marked as significant $\left({ }^{*} p=0.05\right)$ reflect the ranking of all samples in the test group above (or below) samples in the control group. Error bars represent the SD. Primer sequences can be found in Table 1 .

ChIP. For ChIP, dorsal telencephalon was removed from E16 $\mathrm{Nib}^{+/+}$ and $\mathrm{Nfib}^{-1-}$ brains. The ChIP assay was performed using ChIP-IT Express kit (Active Motif) as per the manufacturer's instructions. Antibodies (Active Motif) used were anti-NFIB (\#39091), anti-IgG (\#53011), and anti-H3K27me3 (\#39155). Primer sequences can be found in Table 1.

Luciferase assay. The constructs used in the luciferase assay were a full-length $N f i b$ expression construct ( $f f i b$ pCAGIG-IRES-GFP), a luciferase construct containing 461 base pairs of the upstream promoter region of the mouse Ezh2 gene (Ezh2 Prom), and a luciferase construct in which the -228 site had been mutated (Ezh2 mut Prom; the -228 sequence TTGTTCTTTTGCCAA was mutated to GAGATCTTTTGCCAA). DNA was transfected into Neuro2A cells using FuGene (Promega). Cypridina luciferase was added to each transfection as a normalization control. After $48 \mathrm{~h}$, luciferase activity was measured using a dual luciferase system (Switchgear Genomics). Within each experiment, each treatment was replicated six times. Each experiment was also independently replicated a minimum of three times. The pCAGIG vector alone did not significantly alter Ezh2 promoter-driven luciferase activity (data not shown). Statistical analyses were performed using ANOVA. Error bars indicate the SD.
Table 2. Selected genes downregulated in the Nfib mutant hippocampus at E16

\begin{tabular}{lll}
\hline Common & Fold change & GenBank \\
\hline Robo4 & -1.58 & NM_028783 \\
Sema3a & -1.66 & NM_009152.2 \\
Prox1 & -2.03 & NM_008937.2 \\
Slc1a1 & -2.25 & NM_009199.2 \\
Slc5a1 & -2.26 & NM_019810.3 \\
Gdnf & -2.32 & NM_010275.2 \\
Sema4f & -2.35 & NM_011350 \\
Lhx5 & -2.68 & NM_008499.4 \\
Scn3a & -2.86 & NM_018732.1 \\
Gfap & -3.87 & NM_010277.2 \\
Gdf10 & -5.34 & NM_145741.2 \\
Olig1 & -5.58 & NM_016968.4 \\
Islet 1 & -6.23 & NM_021459.3 \\
\hline
\end{tabular}

A cutoff $p$-value of 0.05 was used for the mean difference between wild-type and Nfib knock-out hippocampal tissue. In addition, a 1.5-fold change filter was imposed on the genes from the ANOVA dataset.

Table 3. Selected genes upregulated in the Nfib mutant hippocampus at E16

\begin{tabular}{lll}
\hline Common & Fold change & Genbank \\
\hline Gli2 & 1.50 & NM_001081125.1 \\
Smarcd3 & 1.60 & NM025891.3 \\
Ezh2 & 1.61 & NM_007971.1 \\
Bmi1 & 1.64 & NM_007552.4 \\
Pou2f2 & 1.71 & NM_011138.1 \\
Pou2f1 & 1.87 & NM_198933.2 \\
Sox3 & 1.96 & NM_009237.1 \\
Nodal & 2.08 & NM_013611.3 \\
MII3 & 2.08 & NM_001081383.1 \\
Sox2 & 2.25 & NM_011443.3 \\
Eya1 & 2.26 & NM_010164.2 \\
Noggin & 2.33 & NM_008711.1 \\
Hes5 & 2.34 & NM_010419.4 \\
Id4 & 2.35 & NM_031166.2 \\
DIl1 & 2.60 & NM_007865.2 \\
Gli3 & 2.61 & NM_008130.2 \\
Pax6 & 4.30 & NM_013627 \\
\hline
\end{tabular}

A cutoff $p$-value of 0.05 was used for the mean difference between wild-type and Nfib knock-out hippocampal tissue. In addition, a 1.5-fold change filter was imposed on the genes from the ANOVA dataset.

Electrophoretic mobility shift assay. Nuclear extracts were isolated from the cortex of E18 brains and from COS cells overexpressing either NFIB of a nonspecific transcription factor, AP2. The electrophoretic mobility shift assay (EMSA) was performed using radiolabeled annealed oligonucleotides containing a control NFI consensus site (Piper et al., 2010) or Ezh2 consensus sites from our bioinformatics screen. EMSA reactions were performed as described previously using $1 \mu \mathrm{g}$ of nuclear extract (Piper et al., 2010). Oligonucleotide sequences were as follows: NFI control, 5' -ggTTTTGGATTGAAGCCAATATGATAA-3' (upper strand), 5' -ggTTATCATATTGGCTTCAATCCAAAA-3' (lower strand); Ezh2294, 5' -ggCCGGGTTGGCGGGACCCGAAC-3' (upper strand), 5' ggCCGGGTTCGGGTCCCGCCAAC-3' (lower strand); Ezh2-294 mut, 5' -ggCCGGGCCGGCGGGACCCGCCC-3' (upper strand), 5' -ggCCGGGGGCGGGTCCCGCCGGC-3' (lower strand); Ezh2-228 5' -ggCCGGGTTGTTCTTTTGCCAAC-3' (upper strand), 5' ggGGCCGGGTTGGCAAAAGAACAAC-3' (lower strand); Ezh2 -228 mut 5' -ggCCGGGTTGTTCTTTTGTCTCC-3' (upper strand), 5' -ggCCGGGGAGACAAAAGAACAAC-3' (lower strand). Supershift assays were performed with either an anti-NFIB antibody (cata$\log$ \#39091; Active Motif), and anti-HA antibody (catalog \#H9658; Sigma) or a control IgG antibody (normal rabbit IgG, catalog \#2729S; Cell Signaling Technology). Additional bases used to generate 5' overhangs for end fill are indicated in lower case.

Cell culture. E14 primary cortical cells were isolated and $1 \times 10^{6}$ cells were electroporated with $10 \mu \mathrm{g}$ of plasmid (Neon Transfection system; Invitrogen). The plasmids used were Nfib pCAGIG-IRES-GFP, pCAGIG-IRES-GFP vector control, Ezh2 shRNA (Origene Technologies; 
A DAVID analysis: Functional annotation of genes up-regulated in $\mathrm{Nfib}^{-/-}$hippocampal tissue

Transcription

Chromosome organization

Regulation of transcription

Chromatin organization

Chromatin organization

Negative regulation of cell differentiation

Negative regulation of cellular biosynthetic process

Regative regulation

RNA processing
Regulation of neurogenesis

mRNA metabolic process

Negative regulation of neuron differentiation

Cell cycle

Posttranscriptional regulation of gene expression

Cell cycle process

Negative regulation of macromolecule biosynthetic process

Negative regulation of gene expression

Regulation of microtubule-based process

Regulation of midance

$171 \quad 5.70 \times 10^{-10}$

$58 \quad 2.63 \times 10^{-9}$

$47-5.45 \times 10^{-9}$

$\begin{array}{ll}47 & 3.20 \times 10^{-7} \\ 38 & 1.18 \times 10^{-7}\end{array}$

$30 \quad 1.94 \times 10^{-6}$

$9.07 \times 10^{-6}$

$1.17 \times 10^{-5}$

$1.41 \times 10^{-5}$
$1.61 \times 10^{-5}$

$1.88 \times 10^{-5}$

$2.33 \times 10^{-5}$

$2.41 \times 10^{-5}$

$3.09 \times 10^{-5}$

$3.32 \times 10^{-5}$

$3.69 \times 10^{-5}$

$3.96 \times 10^{-5}$

$5.03 \times 10^{-5}$

$6.37 \times 10^{-5}$

$8.64 \times 10^{-5}$
Negative regulation of cellular biosynthetic
Negative regulation of biosynthetic process

Negative regulation of macromolecule metabolic proces

Gene count $p$-value

B DAVID analysis: Functional annotation of genes down-regulated in $\mathrm{Nfib}^{-/-}$hippocampal tissue

Ion transport
Cation transport
Muscle organ development
Neural crest cell migration
Mesenchymal cell development
Neural crest cell development
Neural crest cell differentiation
Positive regulation of ion transport
Metal ion transport
Mesenchymal cell differentiation
Positive regulation of immune response
Ameboidal cell migration
Muscle cell development
Mesenchyme development
Actin cytoskeleton organization
Regulation of developmental growth
Cation homeostasis
Autonomic nervous system development
Positive regulation of response to stimulus
Negative regulation of cell motion

$\begin{array}{ll}\text { Gene count } & \text { p-value } \\ 79 & 8.43 \times 10^{-5} \\ 58 & 6.73 \times 10^{-4} \\ 26 & 9.60 \times 10^{-4} \\ 8 & 1.06 \times 10^{-3} \\ 11 & 2.07 \times 10^{-3} \\ 9 & 2.40 \times 10^{-3} \\ 9 & 2.40 \times 10^{-3} \\ 7 & 2.64 \times 10^{-3} \\ 49 & 2.71 \times 10^{-3} \\ 11 & 2.87 \times 10^{-3} \\ 20 & 2.93 \times 10^{-3} \\ 10 & 3.25 \times 10^{-3} \\ 12 & 3.31 \times 10^{-3} \\ 11 & 3.34 \times 10^{-3} \\ 23 & 4.76 \times 10^{-3} \\ 9 & 5.11 \times 10^{-3} \\ 24 & 5.50 \times 10^{-3} \\ 6 & 6.61 \times 10^{-3} \\ 24 & 6.76 \times 10^{-3} \\ 8 & 8.09 \times 10^{-3}\end{array}$

C Functional classification (DAVID)

Transcription

Chromosome reorganization

Up-regulated genes

Gli3; KIf3; KIf9; Pou2f1; Pou2f2; Sox3; Sox5; Sox6; TATA box binding protein; Cux1; Neurogenin 2

4 lysine (K)-specific demethylase 6A; Kdm3b lysine (K)-specific demethylse 3b; SET domain containing (lysine methyltransferase) 7 Helicase-like transcription factor; $\mathrm{Hmg} 2 \mathrm{~A}$ : Histone cluster 1, H2ad; Histone cluster 1, $\mathrm{H} 3 \mathrm{i}$; Histone cluster 1, $\mathrm{H} 4 \mathrm{k}$; Lysine (K)-specific demethylase 4A (and 5A); MII3; MII5; Topioisomsease (DNA) II aplha;

Chromodomain helicase DNA binding protein 1 ; Chromodomain helicase DNA binding protein 7

Histone cluster 2, H3b; Lysine (K)-specific emethylase 2B; Lysine $(K)$-specific demethylase $3 \mathrm{~A}$

Chromatin modification

Ezh2; Bmi1; H2A histone family, member Y2; Smarcc1; Smarcd3; Retino blas

Sox2; Dll1; Hes5; Id4; Pax6

Dicer 1; EphB2; Gli2; Gli3; Nodal; Noggin

Negative regulation of neuron differentatior

Negative regulation of cell differentiation

\section{Down-regulated genes}

Islet 1; Gdnf; Laminin alpha 5; Ret

Elastin; Growth arrest specific 7; Myosin heavy polypeptide 11, smooth muscle; Myosin light polypeptide 2; Profilin 3; Tenascin XB

T-box 5; Fgf9; Microtubule-associated protein tau; Prox1; Sema $4 F$

Robo4; Sema3A; Tropomodulin 3

E
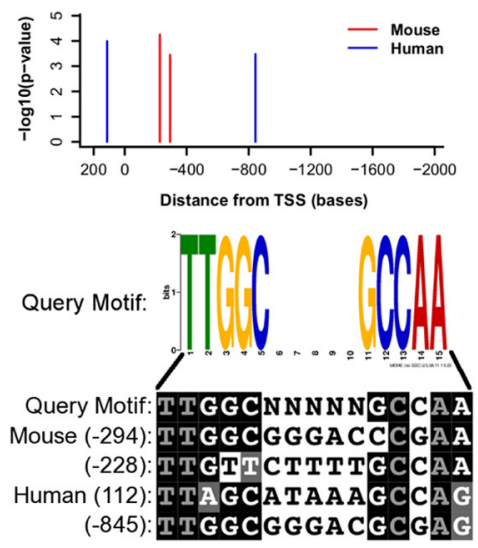

$\mathbf{F}$

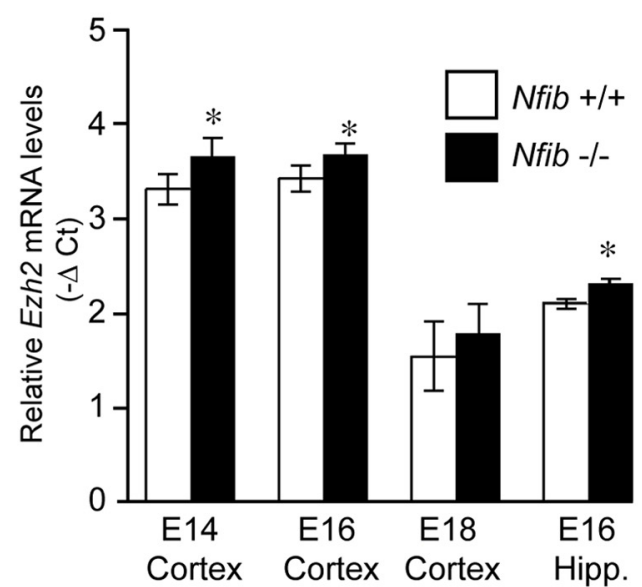

Figure 2. Ezh 2 is a target for transcriptional repression by NFIB. Microarray analysis was performed on E16 $\mathrm{Nfib}^{+/+}$and $\mathrm{Nfib}^{-/-}$hippocampal tissue. Genes were annotated using the Functional Annotation Tool of DAVID, revealing key biological processes that were upregulated $(\boldsymbol{A})$ and downregulated $(\boldsymbol{B})$ in the hippocampus of Nfib ${ }^{-1-}$ mice. Processes associated with chromatin modification were significantly enriched in the mutant mice. Key examples of transcripts upregulated $(\boldsymbol{C})$ or downregulated $(\boldsymbol{D})$ in $N$ fib ${ }^{-1-}$ hippocampal tissue are also shown and include members of the polycomb repressive complexes such as Ezh2 and Bmi, which are both upregulated in the mutant. $\boldsymbol{E}$, An in silico screen for predicted NFI-binding sites identified conserved potential NFI-binding sites within the proximal promoter of the mouse Ezh2 gene and the human EZH2 gene. We report the position of potential sites in bases relative to the transcription start site (TSS) The genomic coordinates (mm9, 1-based) of the two sites in mouse are ( - 228) chr6:47545257- 47545271 and ( - 294) chr6:47545323-47545337.F, qPCR revealed significantly higher Ezh2 mRNA levels in the cortex (E14, E16) and hippocampus (E16) of Nfib $^{-1-}$ mice. ${ }^{*} p=0.05$, Wilcoxon rank-sum test.

the vector encoding this shRNA carries a RFP cassette for selection of transfected cells), Nfib siRNA (Invitrogen; the vector encoding this siRNA carries a GFP cassette for selection of transfected cells), and nonspecific shRNAs and siRNAs. The Ezh2 shRNA caused a significant decrease in Ezh2 mRNA levels $48 \mathrm{~h}$ after transfection (relative transcript levels of Ezh2/Hprt: control $2.02 \pm 0.77$, Ezh2 shRNA $0.68 \pm 0.07, p=$ 0.05 , Wilcoxon rank-sum test). The Nfib siRNA also caused a significant decrease in Nfib mRNA levels (relative transcript levels of Nfib/Hprt: control $20.3 \pm 0.84, N f i b$ siRNA $8.73 \pm 1.78, p=0.05$, Wilcoxon rank-sum test). The control nonspecific shRNAs and siRNAs did not alter endogenous gene transcript levels either individually or in combination (data not shown). The control data represented in Figure 7, $C$ and $D$, represent cells treated with both the nonspecific shRNA and siRNA controls. After electroporation, the cells were immediately returned to growth medium (HEPES-buffered minimal essential medium $+2 \%$ goat serum) and cultured on fibronectin/lysine-coated 


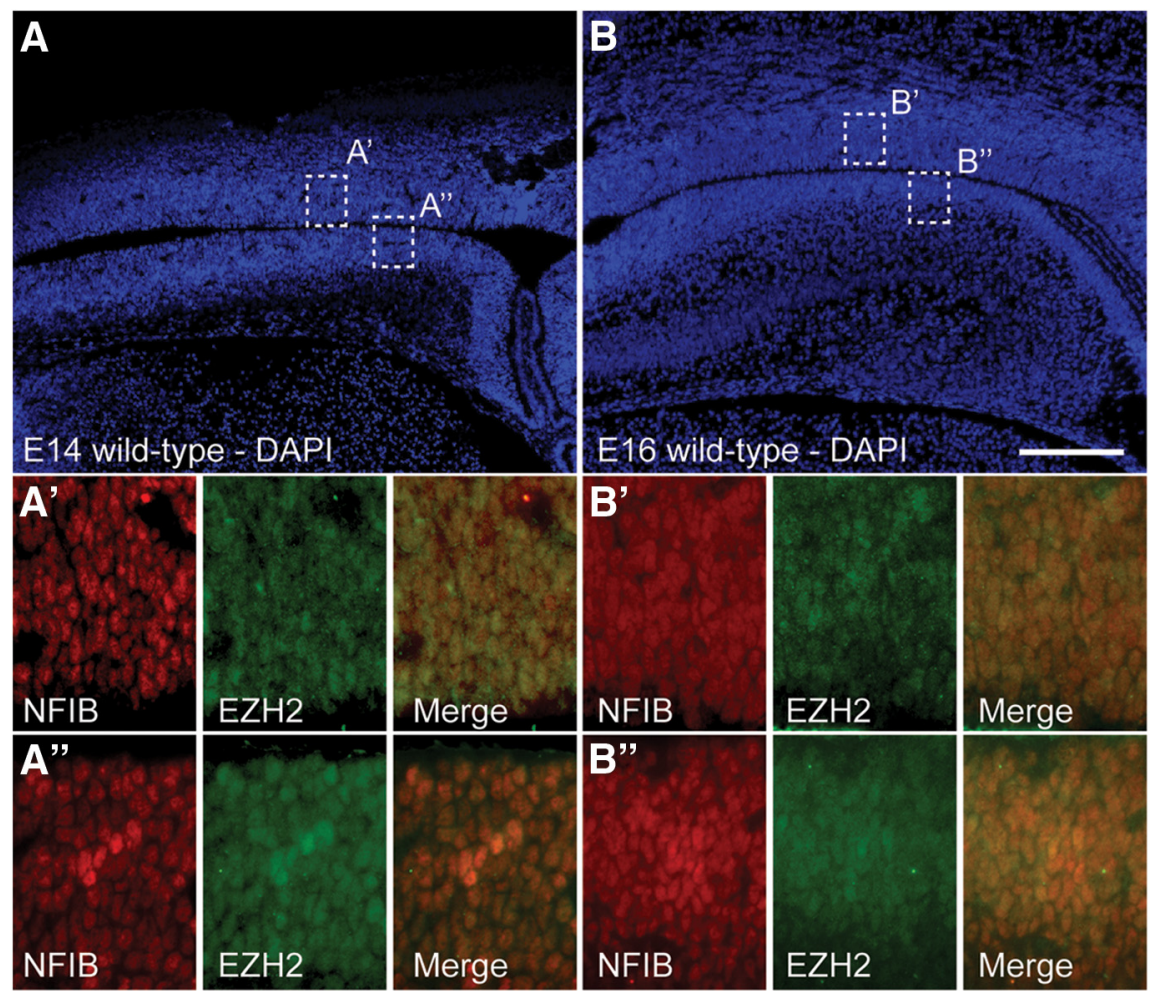

Figure 3. Coexpression of NFIB and EZH2 in neural progenitor cells of the forebrain. Coimmunofluorescence staining of E14 (A) and E16 $(\boldsymbol{B})$ wild-type coronal brain sections at the level of the hippocampus revealing the expression of NFIB (red) and EZH2 (green). $\boldsymbol{A}$ and $\boldsymbol{B}$ are low-power images, with DAPI-stained nuclei (blue) revealing the morphology of the selected sections. Higher-magnification images are taken from the boxed regions in $\boldsymbol{A}$ and $\boldsymbol{B}$, respectively. At E14, neural progenitor cells within the ventricular zone of the neocortex $\left(\boldsymbol{A}^{\prime}\right)$ and hippocampus $\left(\boldsymbol{A}^{\prime \prime}\right)$ coexpress NFIB and EZH2. Similarly, neocortical $\left(\boldsymbol{B}^{\prime}\right)$ and hippocampal $\left(\boldsymbol{B}^{\prime \prime}\right)$ neural progenitor cells express both of these factors at E16. Scale bars: $\boldsymbol{A}, \boldsymbol{B}, 250 \mu \mathrm{m} ; \boldsymbol{A}^{\prime}, \boldsymbol{A}^{\prime \prime}{ }^{\prime}, \boldsymbol{B}^{\prime}, \boldsymbol{B}^{\prime \prime}, 40 \mu \mathrm{m}$.

To determine the mechanism underlying $N f i b$-mediated differentiation of progenitor cells, we performed a microarray study on hippocampi from E16 $N f i b^{-/-}$ and $\mathrm{Nfib}^{+/+}$mice. This analysis identified $>5000$ genes as being differentially expressed within the hippocampus of the mutant mice using a significance level of $p<0.05$ via ANOVA and a fold-change cutoff of 1.5. Genes involved in neuronal and glial differentiation, such as Prox1, Gfap, and Olig1, were downregulated (Table 2), whereas many genes linked to progenitor cell self-renewal, such as Sox2, Dll1, Hes5, and Id4, were upregulated (Table 3). Validation of these findings was done by performing qPCR on mRNA isolated from independent wild-type and mutant hippocampal samples, revealing significant ( $p<0.01, t$ test) downregulation of Prox1 (1.7-fold decrease), Olig1 (1.8-fold decrease), and Gfap (12fold decrease) in samples from the mutant hippocampi. Similarly, significant upregulation ( $p<0.05, t$ test) of Dll1, Sox2, and Sox3 (each exhibited a 1.3fold increase), as well as Hes5 and Id4 (each exhibited a 1.7-fold increase), was observed in samples from the mutant hippocampi.

Interestingly, functional annotation of those genes upregulated in the hippocampus of the mutant mice using the DAVID Bioinformatics Resource showed that

six-well plates. After up to $5 \mathrm{~d}$ in culture, cells were FACS sorted for GFP-positive (pCAGIG vectors, Nfib and control siRNA), RFPpositive (Ezh2 and control shRNA), or GFP- and RFP-positive (both Ezh2 and Nfib knock-down plasmids) transfectants, and the RNA isolated for cDNA synthesis and qPCR analysis. This experiment was also conducted in Neuro2A cells with the following modifications: $3 \times 10^{5}$ cells were transfected with the knock-down constructs using FuGene (Promega) and were sorted via FACS $2 \mathrm{~d}$ after transfection. RNA was subsequently isolated using an RNeasy micro kit (Qiagen).

\section{Results}

Chromatin-modifying factors are upregulated in the hippocampus of $\mathrm{Nib}^{-/-}$mice

Expression of NFIB within ventricular zone neural progenitor cells of the telencephalon is initiated at $\sim \mathrm{E} 12 / \mathrm{E} 13$ and becomes prominent within these cells by E15 (Plachez et al., 2008). Embryonic $N f_{i b}{ }^{-1-}$ mice exhibit subtle delays in neuronal differentiation and severe delays in astrogliogenesis, leading to aberrant hippocampal morphology (Barry et al., 2008). Analysis of the hippocampus of E14, E16, and E18 $\mathrm{Nfib}^{-1-}$ mice revealed that mutant mice also exhibit a significant increase in ventricular zone size at E16 and E18, but not at E14 (Fig. 1A-E). This is coupled with the presence of significantly more cells expressing the progenitor-specific marker PAX6 compared with wild-type littermate controls at E16 and E18 (Fig. 1F-J). Moreover, this phenotype was observed at different positions along the rostrocaudal axis of the mutant brain (Fig. 1). Collectively, these findings are indicative of reduced progenitor cell differentiation within the hippocampus of $\mathrm{Nfib}^{-1-}$ mice. processes involved in the modulation of chromatin structure were highly enriched in the mutant. These included the processes of chromosome reorganization, chromatin organization, and chromatin modification (Fig. $2 A, B$ ), suggesting that NFIB may influence chromatin structure during development. Analysis of transcripts upregulated in the hippocampus of $\mathrm{Nfib}^{-/-}$mice provided further insight into this, with many genes involved in chromosome reorganization and chromatin modification being significantly upregulated in the mutant, including members of the polycomb repressive complexes 1 and 2, such as Ezh2 and Bmi (Fig. 2C,D).

Ezh2 is upregulated in the ventricular zone of $\mathrm{Nfib}^{-/-}$mice Our array findings suggested that NFIB may promote the differentiation of neural progenitor cells via the transcriptional regulation of genes encoding epigenetic regulators. Given the recent identification of the roles played by polycomb repressive complex members in cortical progenitor cell self-renewal (Hirabayashi et al., 2009, Pereira et al., 2010, Sher et al., 2012), we focused on these factors as potential NFIB targets. To identify direct targets of NFIB, we first used an in silico screen searching for the highaffinity NFI-binding site (TTGGC(N5)GCCAA) in the $2 \mathrm{~kb}$ region upstream of the transcription start site of polycomb repressive complex genes, including Ezh2, Eed, Bmi, Cbx2, Cbx3, Suz12, and Ring1b. This screen identified Ezh2 as having two putative, highly conserved NFI-binding motifs in its basal promoter (Fig. 2E), suggesting that repression of Ezh2 transcription may underlie NFIB-mediated neural progenitor cell differentiation. Analysis of independent hippocampal samples at E16 with 

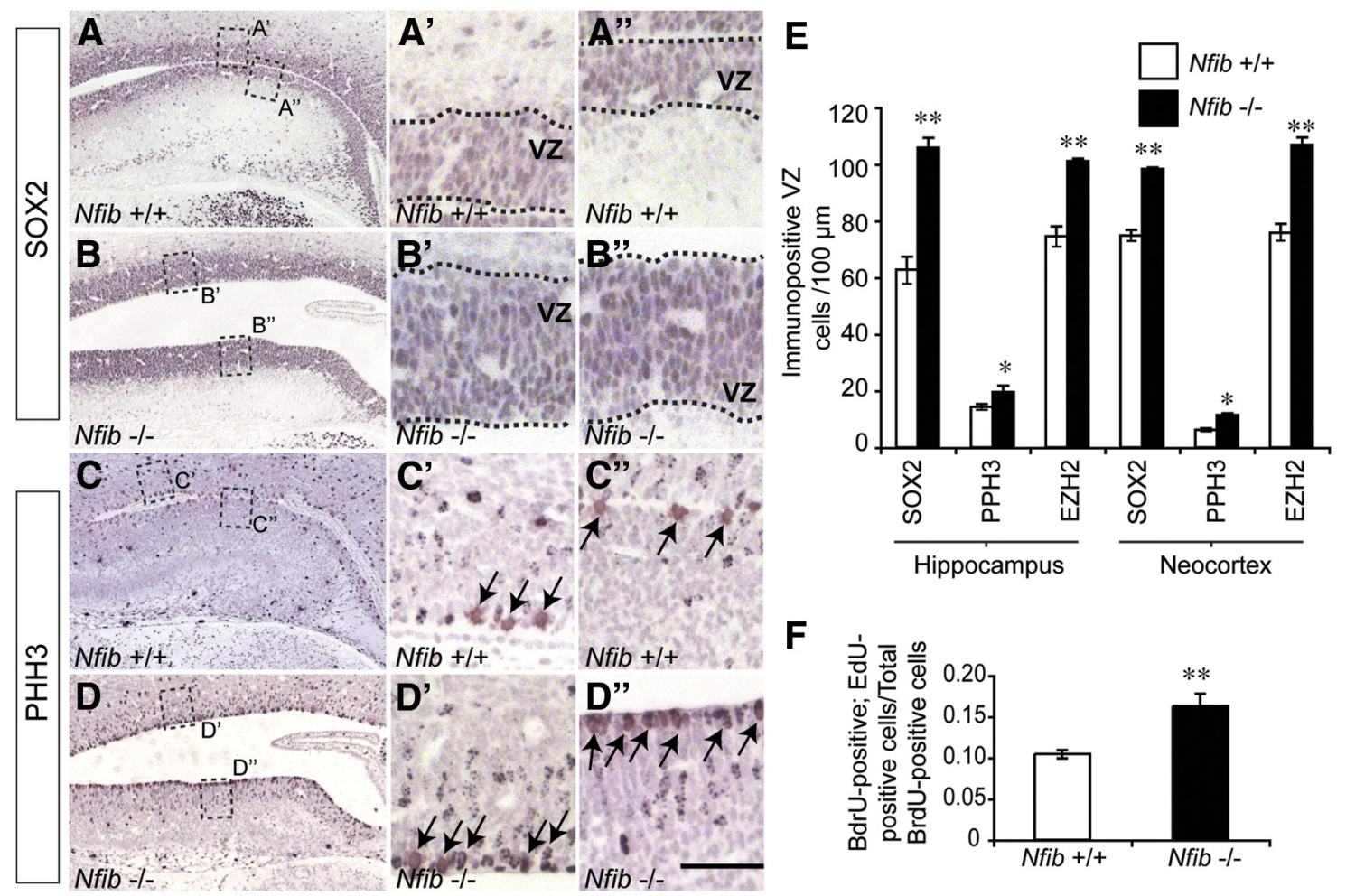

Figure 4. Increased number of proliferating neural progenitor cells in the forebrain of $N$ fib ${ }^{-1-}$ mice. $A-D$, Low-magnification images of coronal sections of E16 hippocampi showing expression of SOX2 $(\boldsymbol{A}, \boldsymbol{B})$ and phosphohistone H3 (PHH3; $\boldsymbol{C}, \boldsymbol{D})$. Higher-magnification images of the neocortical ventricular zone (identified with prime marks) and hippocampal ventricular zone (identified with double prime marks) are shown to the right of each low-power image. In the panels showing SOX2 $(\boldsymbol{A}, \boldsymbol{B})$, the ventricular zone is bounded by the dashed lines. There were significantly more cells expressing SOX2, PHH3 (PHH3-expressing cells in the ventricular zone are shown with arrows in $\boldsymbol{C}^{\prime}, \boldsymbol{C}^{\prime \prime}{ }^{\prime}, \boldsymbol{D}^{\prime}$, and $\boldsymbol{D}^{\prime \prime}$ ), and EZH2 in the neocortical and hippocampal ventricular zone of the mutant at this age compared with the control $(\boldsymbol{E})$. $\boldsymbol{F}$, Proliferating cells were labeled with BrdU at E15 and then with EdU at E16 ( $2 \mathrm{~h}$ before kill) to assess cell cycle exit. The number of cells positive for both BrdU and EdU as a proportion of the total number of BrdU-positive cells was quantified and this proportion was significantly higher within the hippocampus of $N$ fib ${ }^{-1-}$ mice, indicative of reduced cell cycle exit within these mice. ${ }^{*} p<0.05,{ }^{* *} p<0.01, t$ test. VZ, Ventricular zone. Scale bars: $\boldsymbol{A}-\boldsymbol{D}, 250 \mu \mathrm{m} ; \boldsymbol{A}^{\prime} \boldsymbol{A}^{\prime \prime}, \boldsymbol{B}^{\prime}, \boldsymbol{B}^{\prime \prime}, \boldsymbol{C}^{\prime}, \boldsymbol{C}^{\prime \prime}, \boldsymbol{D}^{\prime}, \boldsymbol{D}^{\prime \prime}, 40 \mu \mathrm{m}$.

qPCR confirmed the upregulation of Ezh2 mRNA levels in the hippocampus of $\mathrm{Nfib}^{-l-}$ mice (Fig. $2 \mathrm{~F}$ ). Moreover, Ezh2 levels were also upregulated in the mutant cortex at E14 and E16 (Fig. 2F).

Previous studies have indicated that neural progenitor cells within the ventricular zone of the forebrain express NFIB (Plachez et al., 2008) and EZH2 (Hirabayashi et al., 2009). Coimmunofluorescence staining performed on paraffin sections from E14 and E16 wild-type brains revealed coexpression of these markers within the hippocampal and neocortical ventricular zone, indicating that NFIB and EZH2 are coexpressed in neural progenitor cells (Fig. 3). The increased number of neural progenitor cells in the mutant expressing PAX6 (Fig. 1) suggested that the differentiation of these cells was delayed in $\mathrm{Nfib}^{-/-}$mice. Further evidence to support this came from analysis of the Nfib mutant brains using immunohistochemical detection of the progenitorcell-specific marker SOX2 (Fig. 4A,B) and the mitotic marker phosphohistone $\mathrm{H} 3$ (PHH3; Fig. 4C,D) at E16. This revealed significantly more dividing progenitor cells in the neocortical and hippocampal ventricular zones of $\mathrm{Nfib}^{-1-}$ mice (Fig. $4 E$ ). Furthermore, immunohistochemistry with the chromogen DAB revealed that there were more EZH2-expressing neural progenitor cells (as defined by their elongated nuclei and proximity to the ventricular zone) in the neocortical and hippocampal ventricular zone of the mutant at this age (Fig. $4 E$ and data not shown). We also analyzed cell cycle exit within neural progenitor cells by injecting pregnant $\mathrm{Nfib}^{+/-}$dams with BrdU at E15 and then with EdU at E16 $2 \mathrm{~h}$ before being killed under the rationale that
$N \mathrm{fib}^{-1-}$ mice would exhibit reduced numbers of neural progenitor cells exiting the cell cycle. Indeed, quantification of cells within the hippocampus of knock-out animals confirmed the presence of significantly more cells that were both BrdU and EdU positive as a proportion of the number of total BrdU-positive cells than in the wild-type controls (Fig. $4 F$ ), suggestive of reduced cell cycle exit by progenitors within the mutant hippocampal ventricular zone. Critically, coimmunofluorescence labeling with antibodies against EZH2 and PAX6 revealed that there were significantly more PAX6-positive neural progenitor cells in the neocortical and hippocampal ventricular zone of the mutant mice expressing EZH2 than within wild-type littermate controls (Fig. 5). Collectively, these data suggest that NFIB represses Ezh2 expression and that, in the absence of NFIB, EZH2 levels are elevated and there are increased numbers of proliferating cells within the cortical ventricular zone, so differentiation is delayed.

\section{NFIB is able to regulate Ezh2-promoter driven transcriptional activity}

The presence of the NFI-binding motif in the promoter of the Ezh2 gene is suggestive of NFIB being able to control the transcription of this gene during development. To investigate this, we first investigated whether NFIB could bind to these predicted sites within the Ezh2 promoter. Using EMSA, we determined that a protein from nuclear extracts derived from embryonic cortical tissue bound to one of the two predicted NFI-binding sites ( -228 ; Fig. $2 E$ ). Supershifting of the -228 probe with an antiNFIB antibody indicated that this protein complex contained 

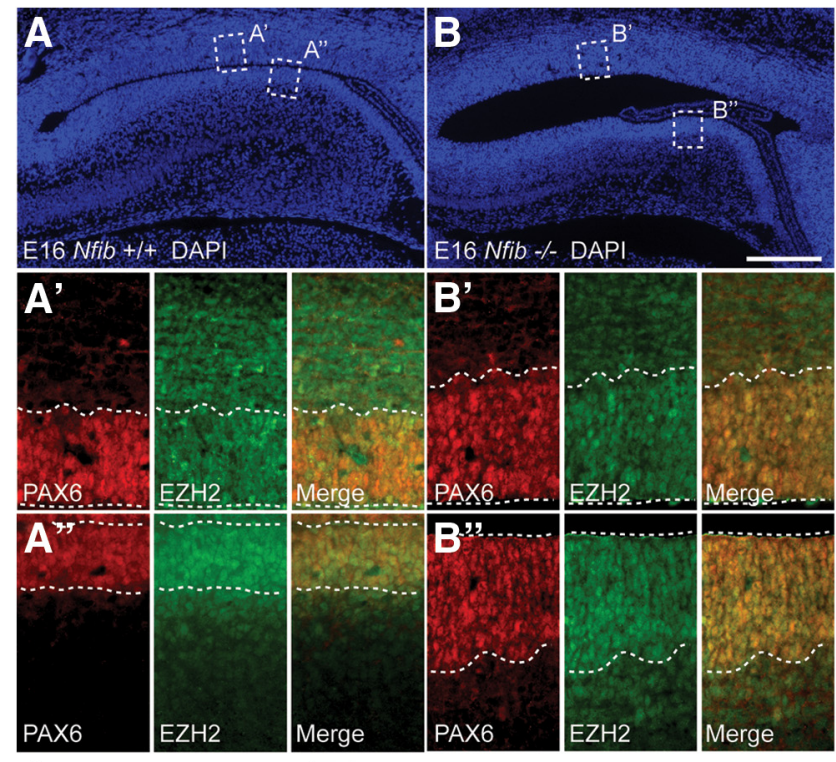

C

Nfib $+/+$

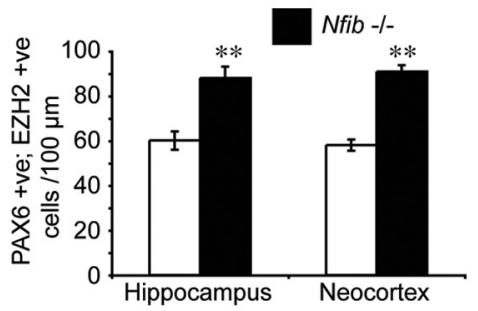

Figure 5. Increased number of EHZ2-expressing neural progenitor cells in the forebrain of $\mathrm{Nfib}^{-1-}$ mice. Coimmunofluorescence labeling of E16 wild-type $(\boldsymbol{A})$ and $\mathrm{Nfib}{ }^{-1-}(\boldsymbol{B})$ coronal brain sections at the level of the hippocampus. $\boldsymbol{A}$ and $\boldsymbol{B}$ are low-power images, with DAPIstained nuclei (blue) revealing the morphology of the selected sections. Higher-magnification images are taken from the boxed regions in $\boldsymbol{A}$ and $\boldsymbol{B}$, respectively. In the wild-type, cells within the neocortical $\left(\boldsymbol{A}^{\prime}\right)$ and hippocampal $\left(\boldsymbol{A}^{\prime \prime}\right)$ ventricular zone express both the neural progenitor cell marker PAX6 and EZH2 (the ventricular in each case is bounded by dashed lines). In the mutant, however $(\boldsymbol{B})$, there are significantly more cells within the ventricular zone of the neocortex $\left(\boldsymbol{B}^{\prime}\right)$ and hippocampus ( $\left.\boldsymbol{B}^{\prime \prime}\right)$ expressing both PAX6 and EZH2 (C). ${ }^{* *} p<0.01, t$ test. VZ, Ventricular zone. Scale bars: $\boldsymbol{A}, \boldsymbol{B}, 250 \mu \mathrm{m} ; \boldsymbol{A}^{\prime} \boldsymbol{A}^{\prime \prime}{ }^{\prime} \boldsymbol{B}^{\prime}, \boldsymbol{B}^{\prime \prime}, 40 \mu \mathrm{m}$.

NFIB (Fig. 6A). A supershift experiment performed with a control antibody that does not recognize NFIB (normal rabbit IgG) did not produce a band with increased electrophoretic mobility (Fig. 6B), reflecting the specificity of this supershift. We next repeated the EMSA experiment using nuclear extracts derived from COS cells expressing an HA-tagged NFIB construct or a tagged nonspecific transcription factor (HA-tagged AP2 construct). Importantly, only the nuclear extract from the NFIBexpressing cells exhibited a supershift when an anti-HA antibody was included in the binding reaction, which is further indicative of the specificity of NFIB binding to the -228 sequence (Fig. $6 C$ ). We also performed an EMSA with a probe in which the -228 site had been mutated. The mutated oligonucleotide did not exhibit a band at the same size as the wild-type -228 probe, indicating that NFIB could no longer bind this sequence (Fig. 6D).

Next, we performed ChIP on wild-type embryonic cortical samples and observed enrichment of NFIB binding to the Ezh2 promoter region containing this predicted NFI-binding site, indicating that NFIB binds to the Ezh2 promoter in vivo (Fig. $6 E$ ). Finally, we used a reporter gene assay (luciferase assay) to determine whether NFIB could regulate Ezh2 promoter-driven gene expression. A 461 base pair region of the mouse Ezh2 promoter that contained the putative NFI motif at -228 was cloned upstream of the luciferase gene. Cotransfection of this construct with an Nfib expression plasmid within Neuro2A cells revealed that NFIB is able to repress Ezh2 promoter-driven transcription in vitro (Fig. $6 F$ ). Importantly, this repression was abolished when the NFI-binding site at -228 in the Ezh2 promoter was mutated (Fig. $6 F$ ). Together, these findings reveal that NFIB occupies the endogenous Ezh2 promoter in vivo and can repress Ezh2 promoter-driven gene expression.

\section{NFIB represses $E z h 2$ expression in primary cortical cells}

These molecular approaches, along with our histological analyses on $\mathrm{Nfib}^{-l-}$ mice, led us to hypothesize that NFIB mediates the repression of Ezh2 transcription. To test this hypothesis, we transfected a Nfib expression construct (carrying an IRES-GFP cassette) into E14 cortical progenitor cells. After 24, 48, or 96 h in culture in vitro, transfected cells were isolated by FACS. GFPpositive cortical cells showed upregulation of $N f i b$ at all time points examined compared with cells transfected with a vectoronly control plasmid (data not shown). At 24 and 48 h after transfection, Ezh2 transcript levels were significantly reduced in GFP-positive cortical cells, although levels at $96 \mathrm{~h}$ were not significantly different from controls (Fig. 7A).

As a member of the polycomb repressive complex 2, EZH2 mediates the trimethylation of lysine residue 27 on histone $\mathrm{H} 3$ (H3K27me3) via its SET domain, culminating in epigenetic repression of target genes (Cao et al., 2002). We hypothesized that downstream targets of EZH2, such as the Ink4A locus, a known target for EZH2-mediated epigenetic repression (Agherbi et al., 2009), would exhibit elevated levels of epigenetic repression. To address this, we used an antibody specific for H3K27me3 and revealed significantly enriched levels of $\mathrm{H} 3 \mathrm{~K} 27 \mathrm{me} 3$ at exons 1 and 2 of the Ink4A locus in $\mathrm{Nfib}^{-1-}$ cortical tissue (Fig. $7 \mathrm{~B}$ ), consistent with the elevated levels of Ezh2 in these mice. Recent reports have suggested that the repression of $I n k 4 A$ results in compensatory increases in the expression of other Ink4 family members (Ramsey et al., 2007, Wiedemeyer et al., 2008). Our data support these findings, demonstrating that the proximal promoter regions of the $\operatorname{Ink} 4 B(p 15, C d k n 2 b), \operatorname{Ink} 4 C(p 18$, $C d k n 2 c)$, and Ink4D ( $p 19, C d k n 2 d)$ loci carried significantly reduced H3K27me3 epigenetic marks, as shown by ChIP with the H3K27me3 antibody (Fig. $7 B$ ). Although these findings provide further evidence for a feedback circuit among Ink4 genes (Wiedemeyer et al., 2008), the mechanisms governing the differential regulation of chromatin modification between family members remains unresolved. Collectively, these data show that NFIB represses Ezh2 expression in cortical cells in vitro and that the elevation of EZH2 expression in $\mathrm{Nfib}^{-1-}$ mice promotes epigenetic changes to a key downstream target gene in vivo.

Finally, we used transient depletion of Ezh2 and/or Nfib in Neuro2A cells to analyze the consequence of the reduction of Ezh2 mRNA in cortical cells that have reduced Nfib levels. In cells expressing $N f i b$ siRNA alone, mRNA levels of Pax 6 were significantly increased. However, when Ezh2 and Nfib were reduced concurrently, the level of Pax 6 mRNA was not significantly different from that of the control (Fig. 7C). A similar outcome was observed with the mRNA of a second progenitor cell marker, nestin (Fig. 7C). These findings were also replicated when we performed this experiment within cultured E14 cortical cells (Fig. 7D), demonstrating that a reduction of Ezh2 expression is sufficient to restore the balance of progenitor cell marker expression induced by depletion of $N f i b$. 
A

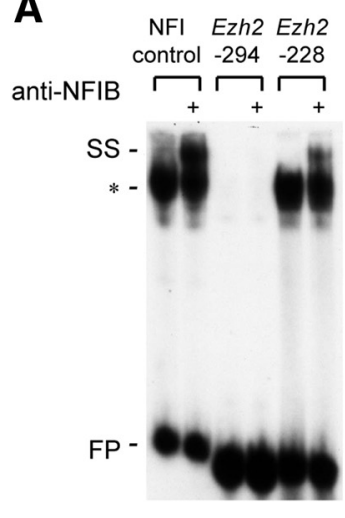

B

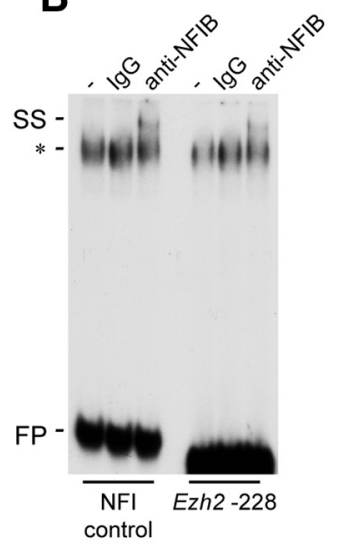

C

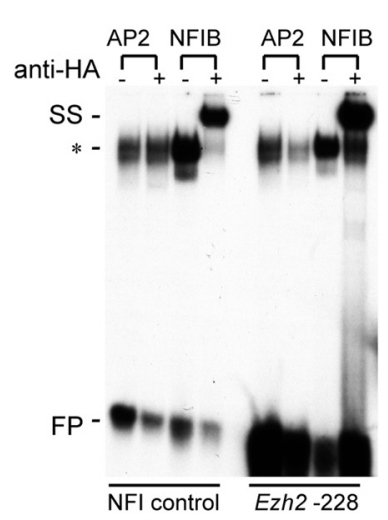

D

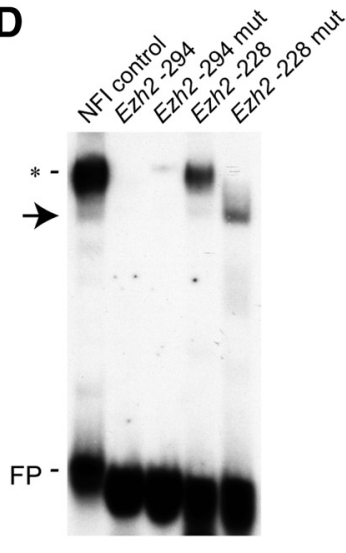

E

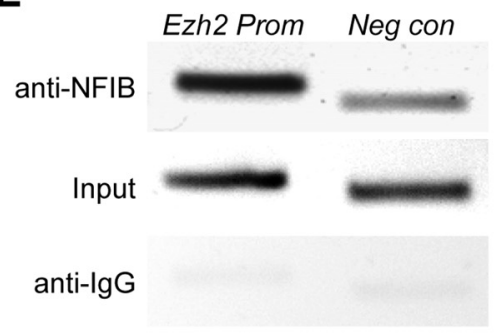

F

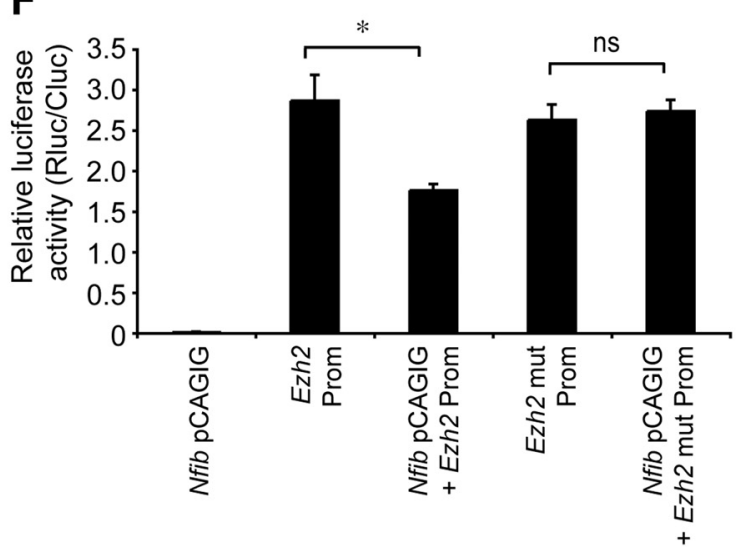

Figure 6. NFIB binds to the promoter of Ezh2 and represses Ezh2 promoter-driven reporter gene activity. $\boldsymbol{A}-\boldsymbol{D}$, Results of EMSA. $\boldsymbol{A}$, E18 mouse brain nuclear extracts were incubated with radiolabeled probes for the NFI control (lanes 1-2) and the -294 (lanes 3-4) or the -228 (lanes 5-6) consensus sites. Binding reactions included anti-NFIB antibodies where indicated. A factor from the nuclear extract bound specifically to the control and the -228 probes. This complex $\left(^{*}\right)$ was supershifted (SS) in the presence of the anti-NFIB antibody. FP, Free probe. $B$, E18 mouse brain nuclear extracts were incubated with radiolabeled probes for the NFI control (lanes 1-3) or the -228 (lanes $4-6$ ) consensus sites. A factor from the nuclear extract bound specifically to these probes. This complex $\left(^{*}\right)$ was supershifted in the presence of the anti-NFIB antibody, but not an IgG control antibody. C, Nuclear extracts from COS cells expressing the transcription factor AP2 or NFIB (both of which carry an HA tag) were incubated with radiolabeled probes for the NFI control (lanes 1-4) or the - 228 (lanes 5-8) consensus sites. A factor from the nuclear extracts bound specifically to these probes $\left(^{*}\right)$. Only the nuclear extract from the COS cells expressing the HA-tagged NFIB construct exhibited a supershift when an anti-HA antibody was included in the binding reaction (lanes 4 and 8). D, E18 mouse brain nuclear extracts were incubated with radiolabeled probes for the NFI control (lane 1) and the -294 (lane 2), mutated - 294 sequence (lane 3), -228 (lane 4), or mutated -228 (lane 5 ) consensus sites. A factor from the nuclear extract bound specifically to the control and the -228 probes $\left({ }^{*}\right)$. A band at the level of the NFI control was no longer observed when the NFI consensus site within the -228 probe was mutated (lane 5). A band was seen at a lower level (arrow), likely indicating that we had created a sequence bound by a different factor. $\boldsymbol{E}$, ChIP assays were conducted on tissue isolated from whole E16 wild-type cortex. DNA fragments immunoprecipitated with control IgG or anti-NFIB antibodies were analyzed by PCR with primers specifically designed to encompass the predicted NFI-binding sites within the Ezh2 promoter. An adjacent region of the Ezh2 promoter lacking a defined NFI-binding site was used as a control. Enrichment of NFIB binding was observed in the promoter region containing the predicted NFI-binding sites. F, Luciferase reporter gene assay performed in Neuro2A cells. NFIB expression (Nfib pCAGIG) elicited no luciferase activity, whereas transfection of an Ezh2 promoter-driven luciferase reporter construct elicited reporter gene induction. Cotransfection of Nfib pCAGIG with the Ezh2 promoter construct resulted in a significantly reduced level of luciferase activity. Mutation of the NFI-binding site at -228 within the Ezh2 promoter abolished NFIB-mediated repression of luciferase activity. ns, Not significant. * $p<0.05$, ANOVA.

\section{Discussion}

The balance between self-renewal and differentiation of multipotent progenitor cells within the embryonic cerebral cortex is central to the development of the mature brain. Epigenetic mechanisms play a critical role in this process, regulating the generation of neuronal and glial lineages from progenitor cells within the developing cortex (Meaney and Ferguson-Smith, 2010). For example, the polycomb group proteins RING1B and EZH2 limit the neurogenic competence of cortical neural progenitors, in part via the epigenetic repression of the proneural target genes such as neurogenin 1 (Hirabayashi et al., 2009), whereas ablation of Ezh2 culminates in a shift from self-renewal toward differentiation within cortical progenitors (Pereira et al., 2010). These data indicate that a central role of EZH2 during telencephalic development is to promote progenitor cell self- renewal. Furthermore, a recent finding revealed that the chromodomain helicase Chd4 plays a key role in regulating polycomb-mediated suppression of Gfap expression via interaction with EZH2 (Sparmann et al., 2013). However, our understanding of how Ezh2 activity is transcriptionally regulated during development and how this affects the differentiation of neural progenitor cells remains unclear.

In this study, we reveal that NFIB regulates the differentiation of embryonic neural progenitor cells in part via repression of Ezh2 transcription. Indeed, the NFI proteins are emerging as pivotal components of the transcriptional program driving neural progenitor cell differentiation. For instance, NFIs have been shown to activate glial-specific (Cebolla and Vallejo, 2006) and neuronal-specific (Wang et al., 2010, Wang et al., 2007) gene expression directly and $\mathrm{Nfi}$-knock-out mice exhibit reduced em- 
A

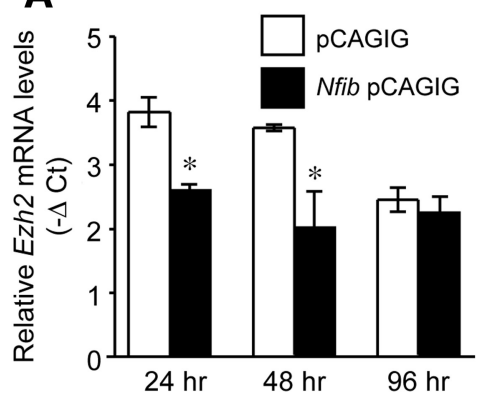

B

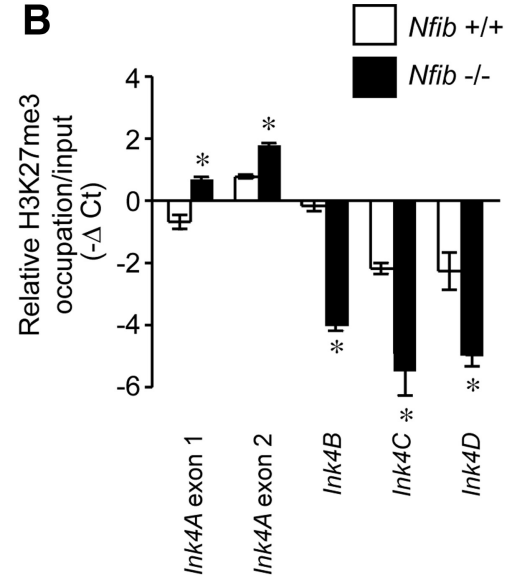

C
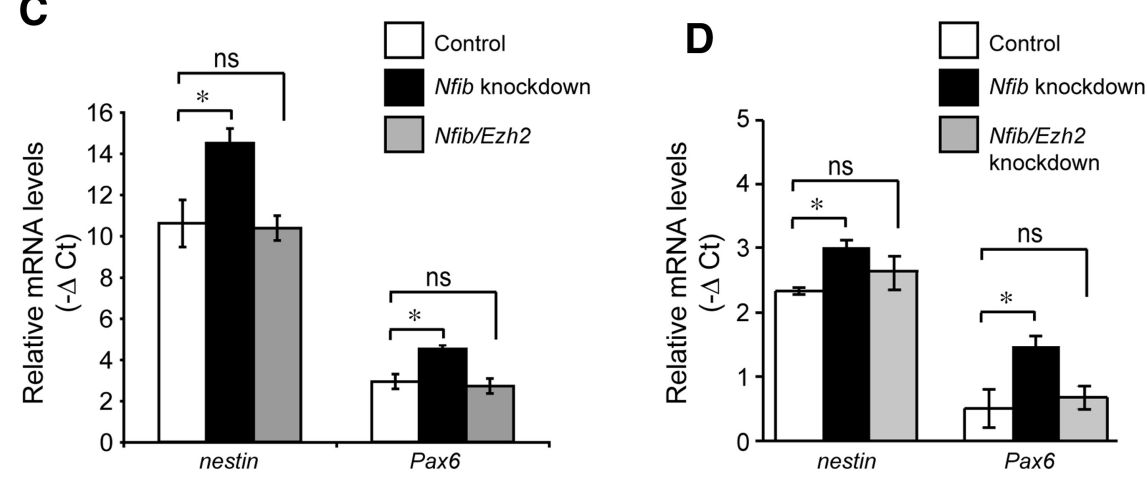

Figure 7. NFIB represses Ezh2 expression in primary cortical cells. $\boldsymbol{A}$, Overexpression of NFIB in E14 cultured cortical neurons revealed significantly reduced levels of Ezh2 $\mathrm{mRNA}$ at 24 and $48 \mathrm{~h}$ after transfection. ${ }^{*} p=0.05$, Wilcoxon rank-sum test. $\boldsymbol{B}$, ChIP using an antibody against H3K27me3 was performed on cells isolated from $\mathrm{E} 16 \mathrm{Nfib}^{+/+}$and $\mathrm{Nfib}^{-1-}$ cortices. qPCR revealed that $\mathrm{Nfib}^{-1-}$ mice exhibited significantly elevated levels of H3K27me3 at exons 1 and 2 of the Ink4A locus relative to input, whereas

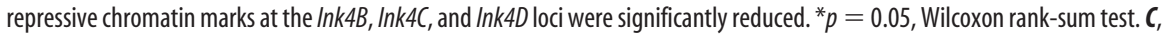
Knock-down of Nfib in Neuro2A revealed significantly increased levels of Pax 6 and nestin mRNA. Levels of each mRNA species were not significantly different from control-treated samples when both Ezh2 and Nfib were knocked down concurrently. ${ }^{*} p=0.05$, Wilcoxon rank-sum test. Similarly, knock-down of Nfib in E14 cortical neurons in vitro (D) revealed significantly increased levels of Pax6 and nestin mRNA. Levels of each mRNA species were not significantly different from control-treated samples when both Ezh2 and Nfib were knocked down concurrently. ${ }^{*} p=0.05$, Wilcoxon rank-sum test.

bryonic astrocytic formation (Barry et al., 2008, das das Neves et al., 1999, Deneen et al., 2006, Heng et al., 2014, Piper et al., 2010, Piper et al., 2011) and delays in neuronal development (Wang et al., 2010, Wang et al., 2007). Interestingly, NFIA has also been implicated in epigenetic control of gene expression, albeit via a different mechanism from that proposed in this study. Binding of NFIA to the Gfap promoter results in the dissociation of DNA methyltransferase 1 from this locus, leading to reduced levels of repressive methylation at the basal Gfap promoter (Namihira et al., 2009).

Our findings are significant in that, although we are beginning to unravel the genetic hierarchy downstream of epigenetic chromatin-modifying proteins such as EZH2, our understanding of the transcriptional control of these genes remains limited. Interestingly, our microarray findings revealed that proteins that function in epigenetic regulation were highly represented in the list of upregulated genes in the $\mathrm{Nfib}^{-1-}$ hippocampus. We focused on Ezh2 due to the presence of conserved, putative NFI-binding sites within the Ezh2 promoter and the previously reported role for EZH2 in the regulation of neural progenitor cell self-renewal. Interestingly, we also identified potential NFI-binding sites in the promoters of Eed, Bmi1, and Cbx2, suggesting that these genes may also be regulatory targets of NFIB during development. Furthermore, although we did not identify NFI-binding sites in the proximal promoters of other genes within the polycomb repressive complexes, we cannot rule out NFIBmediated transcriptional control of these genes from this dataset. Further analysis of NFI-binding sites within the whole genome, including intronic and enhancer regions, followed by in vitro and in vivo validation, will provide a means to assess the extent of direct regulatory control of these genes by NFIB. Future studies aimed at identifying a genome-wide epigenetic profile in the $\mathrm{Nfib}^{-1-}$ cortex may provide a broader understanding of those candidate genes undergoing enhanced epigenetic silencing in the absence of Nfib during development.

\section{References}

Agherbi H, Gaussmann-Wenger A, Verthuy C, Chasson L, Serrano M, Djabali M (2009) Polycomb mediated epigenetic silencing and replication timing at the INK4a/ARF locus during senescence. PLoS One 4:e5622. CrossRef Medline

Barry G, Piper M, Lindwall C, Moldrich R, Mason S, Little E, Sarkar A, Tole S, Gronostajski RM, Richards LJ (2008) Specific glial populations regulate hippocampal morphogenesis. J Neurosci 28:12328-12340. CrossRef Medline

Boyer LA, Plath K, Zeitlinger J, Brambrink T, Medeiros LA, Lee TI, Levine SS, Wernig M, Tajonar A, Ray MK, Bell GW, Otte AP, Vidal M, Gifford DK, Young RA, Jaenisch R (2006) Polycomb complexes repress developmental regulators in murine embryonic stem cells. Nature 441:349-353. CrossRef Medline

Cao R, Wang L, Wang H, Xia L, ErdjumentBromage $\mathrm{H}$, Tempst P, Jones RS, Zhang Y (2002) Role of histone H3 lysine 27 methylation in Polycomb-group silencing. Science 298:1039-1043. CrossRef Medline

Cebolla B, Vallejo M (2006) Nuclear factor-I regulates glial fibrillary acidic protein gene expression in astrocytes differentiated from cortical precursor cells. J Neurochem 97:1057-1070. CrossRef Medline

das Neves L, Duchala CS, Tolentino-Silva F, Haxhiu MA, Colmenares C, Macklin WB, Campbell CE, Butz KG, Gronostajski RM, Godinho F (1999) Disruption of the murine nuclear factor I-A gene (Nfia) results in perinatal lethality, hydrocephalus, and agenesis of the corpus callosum. Proc Natl Acad Sci U S A 96:11946-11951. CrossRef Medline

Deneen B, Ho R, Lukaszewicz A, Hochstim CJ, Gronostajski RM, Anderson DJ (2006) The transcription factor NFIA controls the onset of gliogenesis in the developing spinal cord. Neuron 52:953-968. CrossRef Medline

Heng YH, McLeay RC, Harvey TJ, Smith AG, Barry G, Cato K, Plachez C, Little E, Mason S, Dixon C, Gronostajski RM, Bailey TL, Richards LJ, Piper M (2014) NFIX regulates neural progenitor cell differentiation during hippocampal morphogenesis. Cereb Cortex 24:261-279. CrossRef Medline

Hirabayashi Y, Suzki N, Tsuboi M, Endo TA, Toyoda T, Shinga J, Koseki H, Vidal M, Gotoh Y (2009) Polycomb limits the neurogenic competence of neural precursor cells to promote astrogenic fate transition. Neuron 63:600-613. CrossRef Medline

Huang da W, Sherman BT, Lempicki RA (2009) Systematic and integrative analysis of large gene lists using DAVID bioinformatics resources. Nat Protoc 4:44-57. CrossRef Medline

Kageyama R, Ohtsuka T, Shimojo H, Imayoshi I (2008) Dynamic Notch 
signaling in neural progenitor cells and a revised view of lateral inhibition. Nat Neurosci 11:1247-1251. CrossRef Medline

Lee TI, Jenner RG, Boyer LA, Guenther MG, Levine SS, Kumar RM, Chevalier B, Johnstone SE, Cole MF, Isono K, Koseki H, Fuchikami T, Abe K, Murray HL, Zucker JP, Yuan B, Bell GW, Herbolsheimer E, Hannett NM, Sun K, Odom DT, Otte AP, Volkert TL, Bartel DP, Melton DA, Gifford DK, Jaenisch R, Young RA (2006) Control of developmental regulators by Polycomb in human embryonic stem cells. Cell 125:301-313. CrossRef Medline

Meaney MJ, Ferguson-Smith AC (2010) Epigenetic regulation of the neural transcriptome: the meaning of the marks. Nat Neurosci 13:1313-1318. CrossRef Medline

Namihira M, Kohyama J, Semi K, Sanosaka T, Deneen B, Taga T, Nakashima K (2009) Committed neuronal precursors confer astrocytic potential on residual neural precursor cells. Dev Cell 16:245-255. CrossRef Medline

Pereira JD, Sansom SN, Smith J, Dobenecker MW, Tarakhovsky A, Livesey FJ (2010) Ezh2, the histone methyltransferase of PRC2, regulates the balance between self-renewal and differentiation in the cerebral cortex. Proc Natl Acad Sci U S A 107:15957-15962. CrossRef Medline

Piper M, Moldrich RX, Lindwall C, Little E, Barry G, Mason S, Sunn N, Kurniawan ND, Gronostajski RM, Richards LJ (2009) Multiple noncell-autonomous defects underlie neocortical callosal dysgenesis in Nfibdeficient mice. Neural Dev 4:43. CrossRef Medline

Piper M, Barry G, Hawkins J, Mason S, Lindwall C, Little E, Sarkar A, Smith AG, Moldrich RX, Boyle GM, Tole S, Gronostajski RM, Bailey TL, Richards LJ (2010) NFIA controls telencephalic progenitor cell differentiation through repression of the Notch effector Hes1. J Neurosci 30:9127-9139. CrossRef Medline

Piper M, Harris L, Barry G, Heng YH, Plachez C, Gronostajski RM, Richards LJ (2011) Nuclear factor one X regulates the development of multiple cellular populations in the postnatal cerebellum. J Comp Neurol 519: 3532-3548. CrossRef Medline

Plachez C, Lindwall C, Sunn N, Piper M, Moldrich RX, Campbell CE, Osinski JM, Gronostajski RM, Richards LJ (2008) Nuclear factor I gene expres- sion in the developing forebrain. J Comp Neurol 508:385-401. CrossRef Medline

Ramsey MR, Krishnamurthy J, Pei XH, Torrice C, Lin W, Carrasco DR, Ligon KL, Xiong Y, Sharpless NE (2007) Expression of p16Ink4a compensates for p18Ink4c loss in cyclin-dependent kinase 4/6-dependent tumors and tissues. Cancer Res 67:4732-4741. CrossRef Medline

Sher F, Boddeke E, Olah M, Copray S (2012) Dynamic changes in Ezh2 gene occupancy underlie its involvement in neural stem cell self-renewal and differentiation towards oligodendrocytes. PLoS One 7:e40399. CrossRef Medline

Sparmann A, Xie Y, Verhoeven E, Vermeulen M, Lancini C, Gargiulo G, Hulsman D, Mann M, Knoblich JA, van Lohuizen M (2013) The chromodomain helicase Chd4 is required for Polycomb-mediated inhibition of astroglial differentiation. EMBO J 32:1598-1612. CrossRef Medline

Steele-Perkins G, Plachez C, Butz KG, Yang G, Bachurski CJ, Kinsman SL, Litwack ED, Richards LJ, Gronostajski RM (2005) The transcription factor gene Nfib is essential for both lung maturation and brain development. Mol Cell Biol 25:685-698. CrossRef Medline

Wang W, Mullikin-Kilpatrick D, Crandall JE, Gronostajski RM, Litwack ED, Kilpatrick DL (2007) Nuclear factor I coordinates multiple phases of cerebellar granule cell development via regulation of cell adhesion molecules. J Neurosci 27:6115-6127. CrossRef Medline

Wang W, Crandall JE, Litwack ED, Gronostajski RM, Kilpatrick DL (2010) Targets of the nuclear factor I regulon involved in early and late development of postmitotic cerebellar granule neurons. J Neurosci Res 88:258265. CrossRef Medline

Wiedemeyer R, Brennan C, Heffernan TP, Xiao Y, Mahoney J, Protopopov A, Zheng H, Bignell G, Furnari F, Cavenee WK, Hahn WC, Ichimura K, Collins VP, Chu GC, Stratton MR, Ligon KL, Futreal PA, Chin L (2008) Feedback circuit among INK4 tumor suppressors constrains human glioblastoma development. Cancer Cell 13:355-364. CrossRef Medline

Yuan JS, Reed A, Chen F, Stewart CN Jr 2006 Statistical analysis of real-time PCR data. BMC Bioinformatics 7:85. CrossRef Medline 